In 27 subjects without any disorder of calcium metabolism the plasma calcium, measured four times daily, was significantly reduced when the calcium intake was reduced. The urine calcium also fell significantly.

Eleven normal subjects received a normal and a low-calcium diet on successive days. The ultrafilterable calcium fell significantly on the day of the low calcium intake.

There was a significant correlation between the changes in the plasma and urinary calcium produced by the alteration in the calcium intake. The relative magnitude suggests that if a maximum tubular reabsorptive capacity for calcium exists it was not exceeded under the conditions of these observations.

Thus it would appear that changes in urine calcium brought about by variations in calcium intake could be accounted for by small but significant changes in plasma ultrafilterable calcium.

REFERENCES

Crawford, J. D., Gribetz, D., Diner, W. C., Hurst, P., and Castleman, B. (1957). Endocrinology, 61, 59.

Hodgkinson, A., and Pyrah, L. N. (1958). Brit. F. Surg., 46, 10

Knapp, E. L. (1947). Ұ. clin. Invest., 26, 182.

Nordin, B. E. C. (1960). Clin. Orthop., 17, 235.

- (1961). Advanc. clin. Chem., 4, 275.

(1964). In The Scientific Basis of Medicine: Annual Reviews, 308. Athlone Press, London.

Smith, D. A., and Nordin, B. E. C. (1964). Clin. Sci., 26, 479.

Smith, J. W.' G., Davis, R. H., and Fourman, P (1960), Lancet, 2, 510

Smith, J. A. G., Davis, R. W., H. (1945). \%, Nu (1960). 29 anc

Toribara, T., Y., Terepka, A. R., and Dewey, P. A. (1957). f. clin. Invest., 36, 738 .

Walser, M. (1961). Ibid., 40, 723.

\title{
Renal Artery Stenosis, Hypertension, and Polycythaemia
}

\author{
R. G. LUKE,* M.B., CH.B., M.R.C.P., M.R.C.P.ED. ; A. C. KENNEDY,* M.D., F.R.C.P.ED., F.R.C.P.GLASG. ; \\ W. BARR STIRLING, $\dagger$ CH.M., F.R.C.S.ED. ; F.R.C.S.GLASG.; G. A. MCDONALD, $\ddagger$ M.D., M.C.PATH.
}

Brit. med. F., 1965, 1, 164-166

The association, which in many cases has proved to be a causative one, between renal disease and polycythaemia is now well recognized (Brandt et al., 1963). Reversion of blood values to normal has been demonstrated after removal of hypernephroma (Conley et al., 1957 ; Damon et al., 1958), unilateral polycystic kidney (Jones et al., 1960), hydronephrotic kidney (Cooper and Tuttle, 1957), and a simple renal cyst (Nixon et al., 1960). The great majority of cases described have been in association with neoplastic renal disease (Nixon et al., 1960 ; Jones et al., 1960). It has been suggested (Penington, 1962) that in non-neoplastic renal disease the mechanism of production of the polycythaemia depends on nephrons responding to decreased perfusion by increased production of erythropoietin, a mucoprotein hormone which stimulates erythropoiesis.

We report here a case of renal artery stenosis with severe hypertension and polycythaemia ; after nephrectomy the bloodpressure returned to near normal and blood values returned to complete normality. So far as we are aware this is the first record of the association of polycythaemia with renal ischaemia due to disease of the extrarenal vasculature and of its cure by nephrectomy.

\section{Case Report}

The patient, a man aged 54, of average build, was well until two months before admission (on 21 January 1964), when he developed headache, general malaise, visual impairment, and nocturia. His family history was negative for hypertension, both parents dying at the age of 74, and the past history was unhelpful. The bloodpressure was $240 / 140 \mathrm{~mm}$. $\mathrm{Hg}$, and the fundi showed exudates and haemorrhages and early papilloedema. There was a trace of proteinuria. No abdominal bruit was heard. Culture of the urine was sterile and the blood urea was $24 \mathrm{mg} . / 100 \mathrm{ml}$. Twenty-fourhour endogenous creatinine clearance was $86 \mathrm{ml} . /$ minute. An electrocardiogram was negative. Chest $x$-ray examination showed clear lung fields and some arteriosclerotic change in the aorta without left ventricular hypertrophy. While investigations to exclude renovascular hypertension were undertaken, his hypertension was

* Department of Medicine, the Royal Infirmary, Glasgow.

† Department of Urology, the Royal Infirmary, Glasgow.

$¥$ Department of Haematology, the Royal Infirmary, Glasgow. treated by methyldopa with only partial response; although there was marked visual and fundal improvement with a dose of 2.5 g./day, blood-pressure averaged 190/120 mm. Hg lying and 150/100 $\mathrm{mm}$. $\mathrm{Hg}$ standing even under hospital conditions.

Renal Investigation.-The intravenous pyelogram showed marked disparity in parenchymal mass, the long axis of the right kidney being $9 \mathrm{~cm}$. compared with $13.2 \mathrm{~cm}$. on the left side. The left kidney appeared hypertrophied, with normal caliceal outline, but

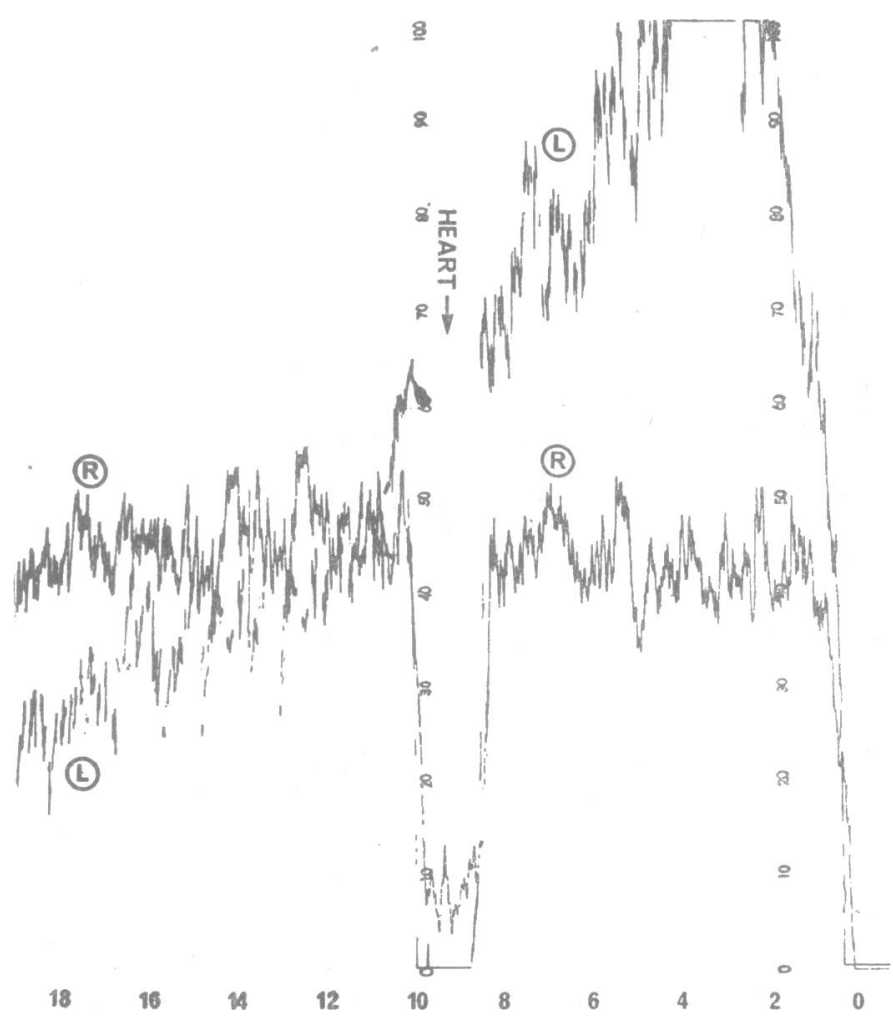

FIG. 1.-Isotope renogram showing normal curve on left side and diminution in vascular and tubular secretory phases on right side and flattening of excretory phase. 
there was delayed and poor right renal function with no caliceal detail. The isotope renogram showed a normal curve on the left side (Fig. 1). On the right side the "vascular" phase and "tubular secretory" phase were very much diminished and the excretory phase was flat. This pattern of curve corresponds closely with that obtained in dogs (Sharpe et al., 1962) when a severe gradient (55 $\mathrm{mm} . \mathrm{Hg}$ ) across the renal artery is produced. Vascular and nephrogram phases of aortogram are shown in Figs. 2 and 3. There is a marked stenosis with apparent complete obstruction over a distance of $1.5 \mathrm{~cm}$. in the proximal part of the right renal artery, and the

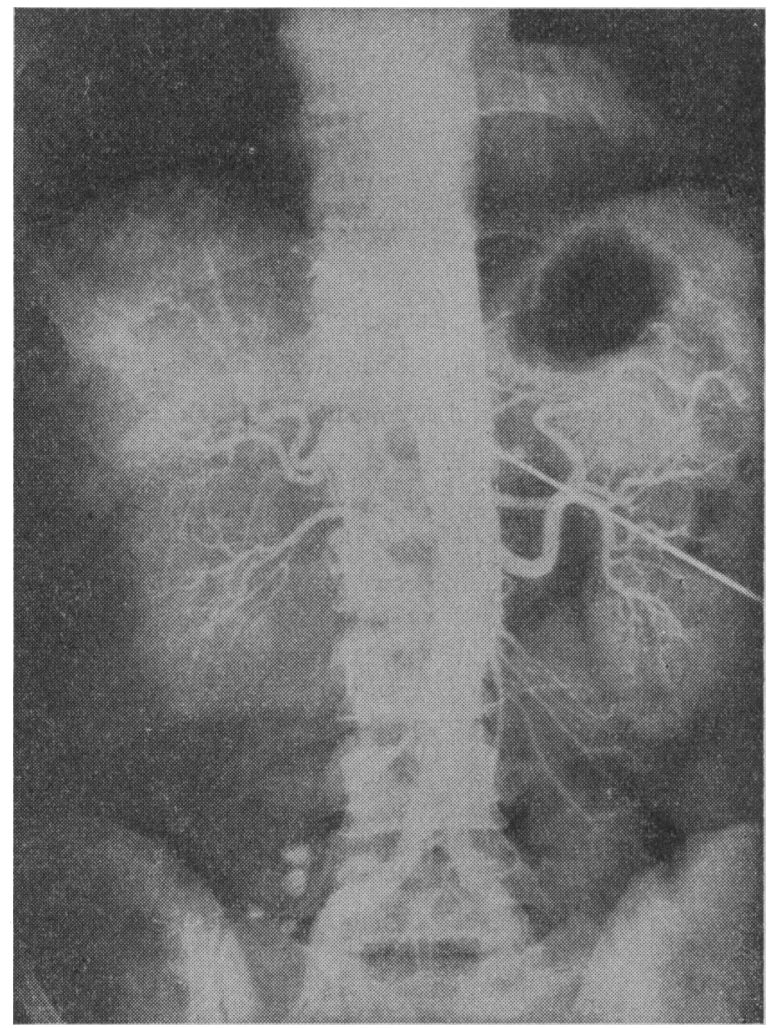

Fig. 2.-Lumbar aortogram showing stenosis of right renal artery.

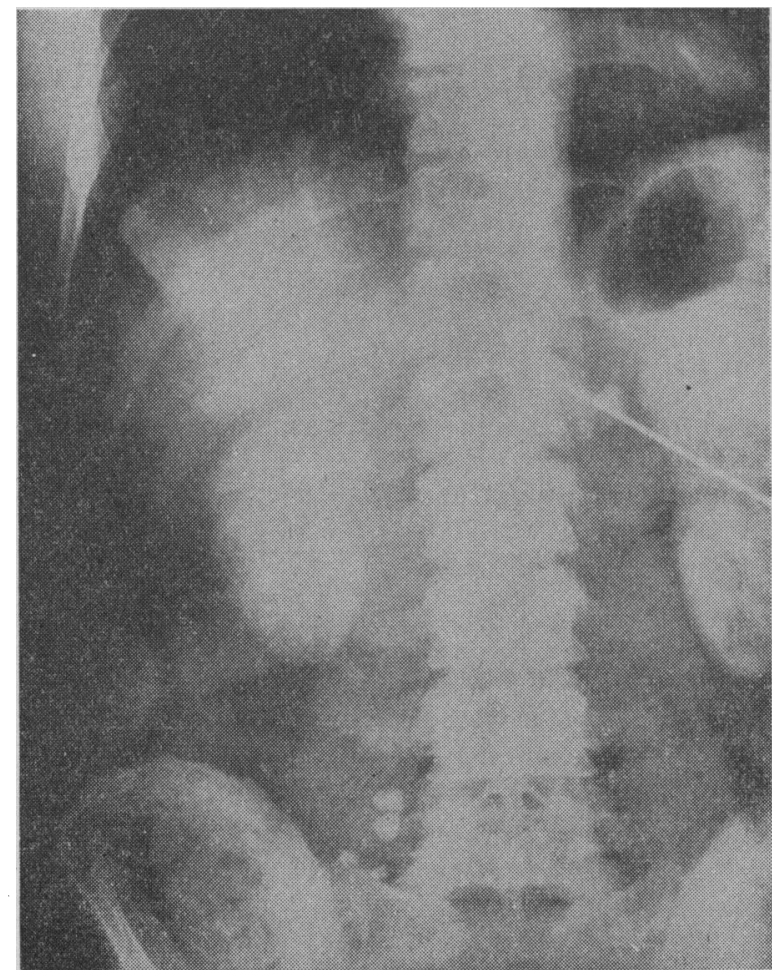

FIG. 3.-Lumbar aortogram showing reduction in size of right kidney. nephrogram phase confirms a much reduced renal parenchymal mass on the right side. Split function tests using a urea diuresis revealed a $50 \%$ diminution in urine flow, an $11 \%$ diminution in sodium concentration, and a $21 \%$ increase in creatinine concentration on the right side. A diagnosis was made of functionally active severe right renal artery stenosis with marked reduction in renal parenchymal mass on that side.

Haematological Aspects.-The haemoglobin was $19.8 \mathrm{~g} . / 100 \mathrm{ml}$. and the P.C.V. $57 \%$. Results of ${ }^{51} \mathrm{Cr}$ blood-volume studies (Mollison and Veall, 1955), shown in the Table, confirm the diagnosis of polycythaemia. The white-cell count and platelet count were normal on several occasions and there was no splenomegaly. The blood uric acid was $4.5 \mathrm{mg} . / 100 \mathrm{ml}$. Venesection was not performed either before or after operation.

Results of ${ }^{51} \mathrm{Cr}$ Blood-volume Studies Before and After Operation (Date of Nephrectomy 28 Februray 1964)

\begin{tabular}{|c|c|c|c|c|c|}
\hline & & \multirow{2}{*}{$\begin{array}{l}\text { Pre-op. } \\
(27 / 2 / 64)\end{array}$} & \multicolumn{2}{|c|}{ Post-operative } & \multirow{2}{*}{$\begin{array}{l}\text { Normal } \\
\text { Values* }\end{array}$} \\
\hline & & & $30 / 4 / 64$ & $1 / 9 / 64$ & \\
\hline $\begin{array}{l}\text { Hb (g./ } / 100 \mathrm{ml} .) \\
\text { P.C.V. }(\%) \\
\text { Red-cell volume }(\ddot{m l} / . / \mathrm{kg} .) \\
\text { Plasma volume (ml./kg.) } \\
\text { Total blood volume (ml./kg.) }\end{array}$ & $\begin{array}{l}\ldots \\
\cdots \\
\cdots\end{array}$ & $\begin{array}{c}19 \cdot 8 \\
57 \\
49 \\
54 \\
103\end{array}$ & $\begin{array}{l}14 \cdot 5 \\
46 \\
34 \\
47 \\
81\end{array}$ & $\begin{array}{l}15 \cdot 1 \\
= \\
=\end{array}$ & $\begin{array}{c}13 \cdot 5-18 \cdot 0 \\
40-54 \\
28-35 \\
40-50 \\
65-85\end{array}$ \\
\hline
\end{tabular}

* Dacie and Lewis (1963).

At operation (W. B. S.) on 28 February the presence of a right renal artery stenosis was confirmed, and direct measurement of aortic and right renal artery pressures revealed a systolic gradient of $120 \mathrm{~mm}$. Hg. The kidney appeared small but otherwise normal. Because of the small size of the kidney revascularization was not attempted and nephrectomy was performed. There was virtually no operative bleeding. The kidney weighed $110 \mathrm{~g}$. and the capsule stripped easily, revealing a smooth congested surface. There was no significant abnormality in the part of renal vasculature attached to the removed kidney. Histology revealed that most of the kidney tissue examined was normal. There was no significant intrarenal arterial abnormality. Very few of the glomeruli were sclerosed and there was some increase in interstitial fibrous tissue with occasional tiny collections of lymphocytes and some dilated tubules with casts. Unfortunately no special stains for the juxta-glomerular apparatus were carried out. His post-operative course was uneventful and the blood-pressure slowly fell in the first week in the absence of hypotensive therapy and was averaging 180/100 $\mathrm{mm}$. $\mathrm{Hg}$ before discharge.

On follow-up six weeks after operation the patient was feeling restored to his normal health and the blood-pressure was 210/100 $\mathrm{mm} . \mathrm{Hg}$ on no treatment. The optic disks were normal, the exudates and haemorrhages had cleared, and there were only minor variations in arteriolar calibre. Repeat chest $x$-ray films and E.C.G. were negative. The haemoglobin was 14.5 g. $/ 100 \mathrm{ml}$. and P.C.V. $46 \%$. Repeat ${ }^{51} \mathrm{Cr}$ studies showed normal values (see Table).

At serial visits up to nine months post-operatively the bloodpressure averaged $190 / 100 \mathrm{~mm}$. $\mathrm{Hg}$ and the blood values have remained normal. The patient has returned to work as a miner.

\section{Discussion}

There is now extensive evidence of the production by the kidney of erythropoietin, reinforced by clinical experience of both anaemia and polycythaemia associated with renal disease (Penington, 1962). Penington postulated an increased production of erythropoietin by nephrons responding to the reduced perfusion, and suggested that with cysts or hydronephrosis increased intrarenal tension and hence reduced renal blood-flow was produced. He stated that factors influencing the rate of perfusion should greatly affect erythropoietic secretion. Renal artery stenosis is believed to cause hypertension in man only when renal blood-flow is reduced (Stamey et al., 1961). In such cases of renovascular hypertension a potent stimulus to erythropoietic production would seem to exist, and it is perhaps surprising that no previous record of the association of renal artery stenosis, hypertension, and polycythaemia is available. Cotes and Lowe (1963) found no significant difference 
between the haemoglobin levels of 10 patients with renal artery stenosis causing hypertension and 10 control patients.

There can be little doubt that in the above patient the hypertension and the polycythaemia were caused by the effects of severe reduction of renal blood-flow, since after nephrectomy there was a reduction in blood-pressure and return of blood values to normal. Osnes (1958) suggested that the juxtaglomerular apparatus might be the site of production of erythropoietin as well as renin, and recent experimental work (Hirashima and Takaku, 1962) has tended to support this hypothesis. Unfortunately no specific stains for the juxtaglomerular apparatus were carried out, but the present case would support the claim that erythropoietin production can be stimulated by reduction in renal blood-flow rather than by renal parenchymal disease per se. There is no indication whether polycythaemia antedated hypertension or vice versa; but certainly the short history does suggest that they probably developed almost simultaneously, and the negative electrocardiogram and chest $x$-ray picture suggest hypertension of short duration.

It is interesting that the features of "primary" polycythaemia were absent-that is, there was no leucocytosis, thrombocytosis, or splenomegaly. Most authors suggest that the absence of these three features should make one consider renal polycythaemia, although the validity of this view is questioned by Brandt et al. (1963).

In 1905 Gaisböck described the syndrome which bears his name. He used the term " polycythaemia hypertonica," which was characterized by polycythaemia without splenomegaly but with hypertension, cyanosis, arteriosclerosis, renal disease, and often cardiac hypertrophy. It is interesting to postulate that some of these patients may indeed have been cases of renal polycythaemia and hypertension, as in the case of Kurrle (1954) with polycystic kidneys, hypertension, and polycythaemia. Perhaps Gaisböck's syndrome is a true entity, being due to renal hypertension and renal polycythaemia, the latter being "secondary" and not associated with splenomegaly.
Arising from this case we would suggest two practical considerations: (1) where polycythaemia is associated with hypertension renal artery stenosis should be considered as well as other renal causes of polycythaemia, and (2) polycythaemia should be looked for in all cases of renovascular hypertension.

\section{Summary}

A case of renal artery stenosis, hypertension, and polycythaemia in a 54-year-old man is presented. Blood values returned to normal and blood-pressure to near normal after nephrectomy. The mechanism of production of " renal" polycythaemia is discussed in the light of this case report.

We are grateful to Dr. A. Muir, Consultant Physician, Law Hospital, who referred this patient to us.

\section{REFERENCES}

Brandt, P. W. T., Dacie, J. V., Steiner, R. E., and Szur, L. (1963). Brit. med. F., 2, 468.

Conley, C. L., Kowal, J., and D'Antonio, J. (1957). Bull. Fohns Hopk. Hosp. 101, 63.

Cooper, W. M., and Tuttle, W. B. (1957). Ann. intern. Med., 47, 1008. Cotes, P. M., and Lowe, R. D. (1963). In Hormones and the Kidney, edited by P. C. Williams, p. 188. Academic Press, London.

Dacie, J. V., and Lewis, S. M. (1963). Practical Haematology, 3rd ed., p. 12. Churchill, London.

Damon, A., Holub, D. A., Melicow, M. M., and Uson, A. C. (1958). Amer. F. Med., 25, 182 .

Gaisböck, F. (1905). Dtsch. Arch. klin. Med., 83, 363.

Gaisböck, F. (1905). Dtsch. Arch. klin. Med., 83, 363.

Jones, N. F., Payne, R. W., Hyde, R. D., and Price, T. M. L. (1960). Lancet, 1, 299.

Kurrle, G. R.' (1954). Med. F. Aust., 1, 777.

Mollison, P. L., and Veall, N. (1955). 'Brit. F. Haemat., 1, 62.

Nixon, R. K., O'Rourke, W., Rupe, C. E., and Korst, D. R. (1960). Arch. intern. Med., 106, 797.

Osnes, S. (1958). Brit. med. F., 2, 1387.

Penington, D. G. (1962). Postgrad. med. F., 38, 497.

Sharpe, A. R., Kontos, H. A., Magee, J. H., and Oates, J. F. (1962). Circulation, 26, 785.

Stamey, T. A., Nudelman, I. J., Good, P. H., Schwentker, F. N., and Hendricks, F. (1961). Medicine (Baltimore), 40, 347.

\title{
Bolus Obstruction of Gut After Use of Hydrophilic Colloid Laxatives
}

\author{
WILLIAM A. SOUTER,* M.B., F.R.C.S.ED.
}

[With Special Plate]

Brit. med. F., 1965, 1, 166-168

Hydrophilic colloid laxatives are of two types-namely, derivatives of natural gums, such as psyllium, and synthetic products based on methylcellulose. As they have a reputation for being a safe form of medication, it may be salutary to draw attention to a serious, if rare, complication of their usenamely, bolus obstruction of the gut. It is the purpose of this paper to report three such cases of obstruction occurring in patients receiving a laxative based on extracts of certain tropical seeds and marketed under the trade name of I-so-gel. The dose in each case was $\frac{1}{2}$ oz. (15 g.) b.d.

\section{Case 1}

A man aged 64, in whom sigmoid diverticulitis had been demonstrated by barium enema in 1957, was admitted to Derbyshire Royal

* Formerly Surgical Registrar, Derbyshire Royal Infirmary.
Infirmary in June 1962 with symptoms and signs of perforated pelvic diverticulitis.

Treatment was effected by pelvic drainage and a defunctioning loop transverse colostomy. Within 48 hours he was passing flatus and some loose faeces from the colostomy. As the stools continued to be profuse and watery in consistence, he was started on I-so-gel medication on the sixth post-operative day. The consistency of the stools thereafter improved and he appeared to make steady progress.

Two days later he complained of some general malaise and nausea. As the colostomy was moving perfectly satisfactorily, no real concern was felt about his general condition. By the following afternoon, however, it was clear that he was far from well. Though the colostomy had again moved satisfactorily, he had developed faecal vomiting and was markedly distended, with a palpable tender mass in the right iliac fossa. A radiograph of the abdomen revealed the surprising finding of gross feculent distension of caecum and ascending colon (Special Plate, Fig. 1). At laparotomy the caecum and colon as far distal as the colostomy were found to contain a vast gelatinous mass of faeces, though no kinking or narrowing of 